\title{
PENGGEROMBOLAN PUSKESMAS KOTA PADANG BERDASARKAN INDIKATOR PERILAKU HIDUP BERSIH DAN SEHAT DENGAN MENGGUNAKAN ANALISIS GEROMBOL
}

\author{
NANDA PRASETYA, IZZATI RAHMI HG, YUDIANTRI ASDI \\ Program Studi Matematika, \\ Fakultas Matematika dan Ilmu Pengetahuan Alam, Universitas Andalas, \\ Kampus UNAND Limau Manis Padang, Indonesia, \\ prasetya837@gmail.com
}

\begin{abstract}
Abstrak. Perilaku hidup bersih dan sehat (PHBS) merupakan salah satu upaya dalam peningkatan derajat kesehatan masyarakat. Didalam kehidupan pada zaman sekarang masyarakat sering melupakan pentingnya menerapkan PHBS di dalam kehidupan sehari-hari. Faktor-faktor yang menyebabkan terjadinya hal tersebut adalah kurangnya pengetahuan, kesadaran ataupun pemberdayaan kepada masyarakat. Perlunya pemberdayaan kepada masyarakat diharapkan dapat meningkatkan derajat kesehatan masyarakat yang salah satunya terhadap peningkatan PHBS. Salah satu organisasi fungsional yang meningkatkan pemberdayaan masyarakat terhadap PHBS adalah puskesmas. Di kota Padang terdapat 22 puskesmas yang secara aktif memberikan pelayanan kepada masyarakat terhadap PHBS. Dari data masing-masing puskesmas terhadap PHBS masyarakat terdapat beberapa daerah yang masih rendah dalam menerapkan PHBS di dalam kehidupan sehari-hari. Perbedaan dapat dilihat dari masing-masing pencapaian puskesmas terhadap indikator PHBS. Karena terjadinya perbedaan tersebut, penggerombolan dilakukan berdasarkan dari data yang diperoleh dari masing-masing puskesmas dengan menggunakan metode gerombol berhirarki dengan jarak yaitu jarak Euclid Kuadrat dan metode perbaikan jarak yaitu metode Ward. Dapat dilihat bahwa gerombol yang terbentuk yaitu berjumlah dua gerombol dimana Gerombol 1 terdiri dari delapan puskesmas (Seberang Padang, Penggambiran, Bungus, Nanggalo, Alai, Anak Air, Pauh, dan Luki) dan Gerombol 2 terdiri dari 14 puskesmas (Pemancung, Ikur Koto, Air Dingin, Kuranji, Ambacang, Rawang Barat, Lubeg, Ulak Karang, Padang Pasir, Andalas, Belimbing, Air Tawar, Lubuk Buaya, Lapai).
\end{abstract}

Kata Kunci: Analisis Gerombol Berhirarki, Jarak Euclid Kuadrat, Metode Ward

\section{Pendahuluan}

Derajat kesehatan merupakan salah satu ukuran kesejahteraan dan kualitas sumber daya manusia. Upaya peningkatan derajat kesehatan masyarakat secara tidak langsung akan meningkatkan kualitas masyarakat. Peningkatan derajat kesehatan perlu dilakukan dengan serius diantaranya melalui peningkatan pengetahuan mengenai perilaku hidup bersih dan sehat. Hal tersebut tidak lepas dari peran pemerintah dengan mendukung ketersedian sarana dan prasarana kesehatan yang memadai sehingga dapat dinikmati oleh seluruh lapisan masyarakat serta peran masyarakat dalam perilaku hidup sehat, memelihara, dan melindungi kesehatan diri dan lingkungan yang khususnya di lingkungan rumah tangga. Perilaku hidup 
bersih dan sehat rumah tangga adalah upaya untuk memberdayakan anggota rumah tangga agar tahu, mau dan mampu mempraktikkan perilaku hidup bersih dan sehat serta berperan aktif dalam gerakan kesehatan di masyarakat [3]. Derajat kesehatan yang dapat diukur melalui indikator perilaku hidup bersih dan sehat (PHBS) diantaranya yaitu, persalinan kesehatan, memberi ASI eksklusif, menimbang balita, air bersih, mencuci tangan dengan air bersih dan sabun (CPTS), menggunakan jamban sehat, memberantas jentik, makan sayur dan buah, melaukan akftifitas fisik, dan perilaku tidak merokok di rumah. Dengan memperhatikan indikator di atas akan didapat gambaran kondisi pengetahuan masyarakat mengenai perilaku hidup bersih dan sehat di setiap daerah.

Puskesmas adalah suatu kesatuan organisasi fungsional yang memberikan pelayanan langsung secara menyeluruh kepada masyarakat dalam satu wilayah kerja tertentu dalam bentuk usaha-usaha kesehatan pokok. Salah satu bagian dari puskesmas dalam meningkatkan derajat kesehatan masyarakat yaitu Promkes (Promosi Kesehatan). Promkes mempunyai peran yang sangat penting dalam proses pemberdayaan masyarakat khususnya dalam kegiatan meningkatkan perilaku hidup bersih dan sehat pada masyarakat di lingkungan rumah tangga. Di kota Padang terdapat 22 puskesmas yang secara aktif memberikan pelayanan kesehatan kepada masyarakat. Salah satu pelayanan puskesmas tersebut adalah memberikan pembinaan masyarakat terhadap perilaku hidup bersih dan sehat. Masyarakat di kota Padang pada umumnya memiliki pengetahuan terhadap perilaku hidup bersih dan sehat namun kenyataan yang terjadi masih terdapatnya masyarakat yang belum menerapkan perilaku hidup bersih dan sehat dalam kehidupan sehari-hari. Hal tersebut dapat dilihat dari data masing-masing puskesmas di kota Padang. Kondisi masyarakat tersebut membuat data dari masing-masing puskesmas mengalami perbedaan pencapaian terhadap indikator perilaku hidup bersih dan sehat.

Penelitian ini mencoba menggerombolkan puskesmaspuskesmas di kota Padang dengan menggunakan indikator perilaku hidup bersih dan sehat. Salah satu analisis statistika yang dapat digunakan untuk menggerombolkan puskesmas-puskesmas yang ada di kota Padang adalah analisis gerombol. Analisis gerombol adalah suatu teknik analisis statistika peubah ganda yang dapat digunakan untuk mengelompokkan objek-objek ke dalam beberapa gerombol berdasarkan peubah-peubah yang diamati pada objek-objek tersebut.

\section{Metode Ward}

Metode Ward adalah metode gerombol berhirarki yang bersifat penggabungan untuk memperoleh gerombol yang memiliki varian internal sekecil mungkin. Metode Penggabungan merupakan prosedur pengelompokan hirarki dimana setiap objek berawal dari gerombol yang terpisah. Gerombol-gerombol dibentuk dengan mengelompokkan objek ke dalam gerombol yang semakin banyak objek yang menjadi anggotanya. Proses ini dilanjutkan sampai semua objek menjadi anggota dari gerombol tunggal. Metode Ward merupakan bagian dari metode pengelompokan yang mengelompokkan $N$ buah objek ke dalam gerombol dengan banyaknya gerombol tidak diketahui. Metode Ward berusaha untuk meminimalkan variasi antar ob- 
jek yang ada dalam satu cluster dan memaksimalkan variasi dengan objek yang ada di cluster lainnya.

Misalkan objek $U$ dan $V$ digabung menjadi gerombol $(U V)$. Ukuran jarak antara gerombol $(U V)$ dan gerombol lainya, misalkan $W$ dirumuskan sebagai berikut:

$$
d_{(u v, w)}^{2}=\frac{N_{u}+N_{w}}{N_{u}+N_{v}+N_{w}} d_{(u, w)}^{2}+\frac{N_{v}+N_{w}}{N_{u}+N_{v}+N_{w}} d_{(v, w)}^{2}-\frac{N_{w}}{N_{u}+N_{v}+N_{w}} d_{(u, v)}^{2}
$$

dengan:

$$
\begin{aligned}
N_{u} & : \text { jumlah objek dalam gerombol } U . \\
N_{v} & : \text { jumlah objek dalam gerombol } V . \\
N_{w} & : \text { jumlah objek dalam gerombol } W . \\
d_{u, v}^{2} & : \text { jarak antara gerombol } U \text { dan } V . \\
d_{u, w}^{2} & : \text { jarak antara gerombol } U \text { dan } W . \\
d_{v, w}^{2} & : \text { jarak antara gerombol } V \text { dan } W .
\end{aligned}
$$

Untuk menginterpretasikan gerombol yang terbentuk yaitu dengan melihat ratarata nilai objek yang terdapat dalam masing-masing gerombol pada setiap variabel. Rata-rata gerombol ke-i dihitung dengan menggunakan rumus sebagai berikut:

$$
V_{i}=\frac{\sum_{(i)=1}^{n} y_{i}}{n}
$$

Dengan adalah rata-rata nilai objek pada gerombol ke-i, adalah objek ke-i, dan $\mathrm{n}$ adalah banyaknya objek atau jumlah gerombol yang menjadi anggota ke-i. Variabel dari indikator Perilaku Hidup Bersih dan Sehat dapat dilihat pada Gambar 1 berikut.

\begin{tabular}{|c|c|}
\hline No. & Indikator (Peubah) PHBS \\
\hline$V_{1}$ & Persalinan Kesehatan (Linakes) \\
\hline$V_{2}$ & Memberi ASI Eksklusif \\
\hline$V_{3}$ & Menimbang Balita Setiap Bulan \\
\hline$V_{4}$ & Air Bersih \\
\hline$V_{5}$ & CTPS \\
\hline$V_{6}$ & Menggunakan Jamban Sehat \\
\hline$V_{7}$ & Memberantas Jentik di Rumah \\
\hline$V_{8}$ & Makan Sayur dan Buah-buahan \\
\hline$V_{9}$ & Melakukan Aktifitas Fisik \\
\hline$V_{10}$ & Tidak Merokok di Rumah \\
\hline
\end{tabular}

Gambar 1. Variabel Indikator Perilaku Hidup Bersih dan Sehat

\section{Hasil dan Pembahasan}

Data yang digunakan dalam penelitian ini diperoleh dari Promosi Kesehatan dan Pemberdayaan Masyarakat tahun 2015 yang diambil dari Dinas Kesehatan Kota Padang. Data ini merupakan hasil dari Program Kerja Promosi Kesehatan dan 
Pemberdayaan Masyarakat Kota Padang yang dilakukan pada tahun 2014. Kota Padang teridiri dari 22 puskesmas yang secara aktif memberikan pelayanan langsung kepada masyarakat dalam suatu wilayah kerja. Dengan sepuluh variabel (Peubah) dari indikator PHBS akan dilakukan analisis gerombol berhirarki penggabungan dengan menggunakan jarak Euclid Kuadrat dan metode perbaikan jarak yang digunakan adalah Metode Ward. Hasil yang diperoleh dari analisis penggerombolan berhirarki dari 22 puskesmas kota Padang terhadap indikator PHBS akan dideskripsikan dengan menggunakan diagram garis dengan mencari rata-rata dari untuk data yang telah digerombolkan, menjelaskan gerombol yang terbentuk dengan mengamati karakteristik dari masing-masing gerombol dan membedakan suatu gerombol dengan gerombol yang lain. Berikut ditampilkan hasil proses penggerombolan 22 puskesmas yang ada di kota Padang.

\begin{tabular}{|c|r|r|r|c|}
\hline Tahap & $\begin{array}{l}\text { Jumlah } \\
\text { Gerombol }\end{array}$ & Jarak & Gerombol yang digabung & $\begin{array}{c}\text { Jumlah } \\
\text { Puskesmas } \\
\text { dalam } \\
\text { gerombol }\end{array}$ \\
\hline 1 & 21 & 734 & $(3),(20)$ & 2 \\
\hline 2 & 20 & 791 & $(7),(9)$ & 2 \\
\hline 3 & 19 & 813 & $(15),(17)$ & 2 \\
\hline 4 & 18 & 910 & $(4),(8)$ & 2 \\
\hline 5 & 17 & 1102 & $(3.20),(5)$ & 3 \\
\hline 6 & 16 & 1339 & $(4.8),(16)$ & 3 \\
\hline 7 & 15 & 1808 & $(2),(12)$ & 2 \\
\hline 8 & 14 & 1826 & $(10),(15.17)$ & 3 \\
\hline 9 & 13 & 2100 & $(4.8 .16),(7.9)$ & 5 \\
\hline 10 & 12 & 3074 & $(21),(22)$ & 2 \\
\hline 11 & 11 & 3242 & $(18),(19)$ & 2 \\
\hline 12 & 10 & 3443 & $(2.12),(10.15 .17)$ & 5 \\
\hline 13 & 9 & 5184 & $(1),(21.22)$ & 3 \\
\hline 14 & 8 & 6338 & $(3.20 .5),(4.8 .16 .7 .9)$ & 8 \\
\hline 15 & 7 & 6420 & $(11),(18.19)$ & 3 \\
\hline 16 & 6 & 7864 & $(6),(11.18 .19)$ & 4 \\
\hline 17 & 5 & 9560 & $(1.21 .22),(13)$ & 4 \\
\hline 18 & 4 & 10678 & $(2.12 .10 .15 .17),(3.20 .5 .4 .8 .16 .7 .9)$ & 13 \\
\hline 19 & 3 & 11340 & $(1.21 .22 .13),(6.11 .18 .19)$ & 8 \\
\hline 20 & 2 & 13427 & $(2.12 .10 .15 .17 .3 .20 .5 .4 .8 .16 .7 .9),(14)$ & 14 \\
\hline 21 & 1 & 100741 & $(1.21 .22 .13 .6 .11 .18 .19)$, & 22 \\
\hline
\end{tabular}

Gambar 2. Hasil Pengamatan dari Analisis Gerombol

Hasil dari penggerombolan dengan menggunakan analisis gerombol berdasarkan tabel pada Gambar 2 disajikan dalam bentuk dendogram yang dapat dilihat pada Gambar 3 berikut. 


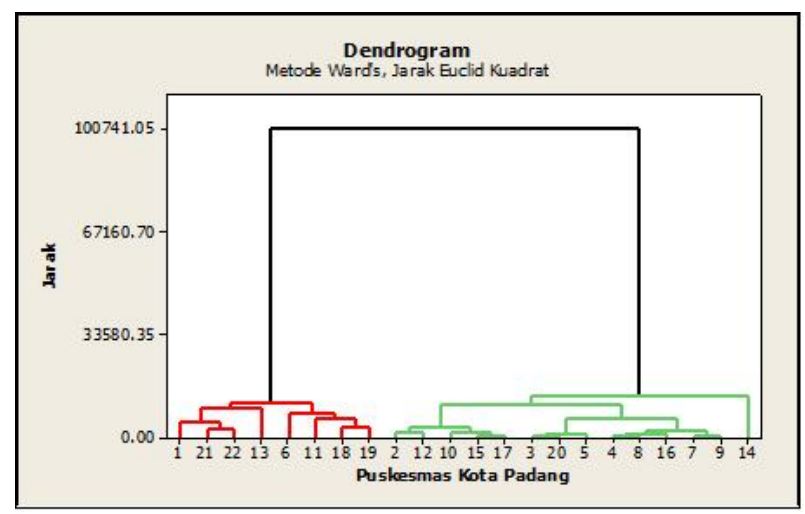

Gambar 3.1 Dendogram Hasil Penggerombolan 22 Puskesmas Kota Padang

Berikut adalah penomoran puskesmas berdasarkan Dendogram pada Gambar 3.
1. Seberang Padang 12. Ikur Koto
2. Pemancung 13. Nanggalo
3. Rawang Barat 14. Lapai
4. Padang Pasir 15. Kuranji
5. Ulak Karang 16. Belimbing
6. Alai 17. Ambacang
7. Air Tawar 18. Pauh
8. Andalas 19. Lubuk Kilangan
9. Lubuk Buaya 20. Lubuk Begalung
10. Air Dingin 21. Pengambiran
11. Anak Air 22. Bungus

Dari dendogram yang diperlihatkan di atas, diketahui bahwa selisih jarak penggabungan terbesar terjadi pada jarak 100741 dengan 13427 yaitu sebesar 87314 seperti yang diperlihatkan dengan garis pada Gambar 3.1. Banyak gerombol yang akan dibentuk ditentukan berdasarkan selisih jarak penggabungan terbesar. Bila dilakukan pemotongan pada jarak ini maka akan diperoleh dua gerombol yaitu.

(1) Gerombol 1 teridiri dari delapan puskesmas yaitu Puskesmas Seberang Padang, Pengambiran, Bungus, Naggalo, Alai, Anak Air, Pauh, dan Luki.

(2) Gerombol 2 terdiri dari 14 puskesmas yaitu Puskesmas Pemancung, Ikur Koto, Air Dingin, Kuranji, Ambacang, Rawang Barat, Lubeg, Ulak Karang, Padang Pasir, Andalas, Belimbing, Air Tawar, Lubuk Buaya, dan Lapai.

Nilai rata-rata setiap indikator pada masing-masing gerombol akan ditunjukkan dalam bentuk diagram garis untuk masing-masing indikator perilaku hidup bersih dan sehat. Berikut akan dideskripsikan karakteristik dari kedua gerombol yang terbentuk.

Dari Gambar 3.2, dapat dilihat bahwa secara umum Gerombol 2 memiliki nilai yang lebih tinggi dari Gerombol 1 terhadap 10 indikator PHBS. Apabila dilihat dari nilai rata-rata yang lebih tinggi dari sepuluh indikator PHBS terdapat pada in- 


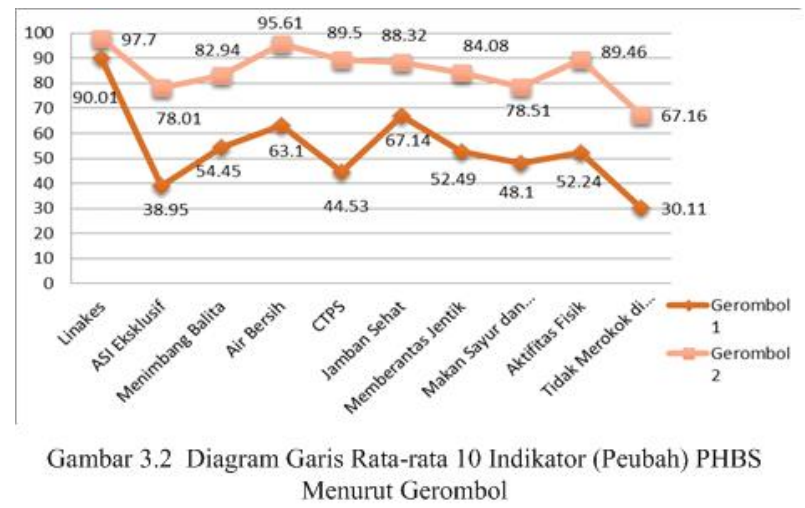

dikator Linakes, sedangkan nilai rata-rata yang lebih rendah dari sepuluh indikator PHBS terdapat pada indikator tidak merokok di rumah.

Pada indikator Linakes dapat dilihat bahwa nilai rata-rata yang terdapat pada Gerombol 1 tidak jauh berbeda dari Gerombol 2 yang masih berkisar pada jarak 90.00-100. Perbedaan diantara Gerombol 1 dan Gerombol 2 yaitu sebesar 7.6. Ini berarti bahwa tenaga kesehatan yang sudah membantu masyarakat dalam persalinan kesehatan pada masing-masing puskesmas yang ada di Gerombol 1 dan Gerombol 2 sudah sangat baik.

Perbedaan yang sangat mencolok terjadi pada indikator tidak merokok di rumah. Dari Gambar 3.2 dapat dilihat bahwa nilai rata-rata pada indikator tidak merokok di rumah pada Gerombol 1 sangat rendah dibandingkan dengan Gerombol 2 yaitu sebesar 30.11. Perbedaan nilai diantara Gerombol 1 dan Gerombol 2 cukup jauh yaitu sebesar 37.05. Ini berarti bahwa rata-rata tingkat keberhasilan pada masing-masing puskesmas yang ada di Gerombol 1 masih sangat rendah dibandingkan puskesmas yang ada di Gerombol 2 dalam melakukan program PHBS pada indikator tidak merokok di rumah, karena memiliki perbedaan nilai yang cukup jauh.

Pada Tabel 3.2 akan diperlihatkan tabel persentase keberhasilan indikator PHBS berdasarkan kriteria keberhasilan terhadap masing-masing puskesmas pada Gerombol 1 dan Gerombol 2.

Berdasarkan tabel di atas dapat dilihat bahwa Gerombol 2 menampilkan tingkat keberhasilan yang lebih tinggi atau sangat baik dari Gerombol 1. Gerombol 1 memiliki tingkat keberhasilan yang sangat rendah namun, terdapat tiga indikator yang masih menampilkan nilai yang baik dan cukup baik, yaitu pada indikator Persalinan Kesehatan, Air Bersih, dan Menggunakan Jamban Sehat.

\section{Kesimpulan dan Saran}

\subsection{Kesimpulan}

Berdasarkan hasil dan pembahasan dalam penelitian ini, maka dapat disimpulkan bahwa hasil penggerombolan 22 puskesmas di kota Padang berdasarkan indikator (peubah) perilaku hidup bersih dan sehat tahun 2014 menghasilkan dua gerombol, sebagai berikut. 
Tabel 3.2 Tingkat Keberhasilan Gerombol 1 dan Gerombol 2 Pada Masing-masing Indikator (Peubah) PHBS

\begin{tabular}{|c|c|c|c|c|c|}
\hline \multirow{2}{*}{ No. } & \multirow{2}{*}{$\begin{array}{c}\text { Indikator (Peubah) } \\
\text { PHBS }\end{array}$} & \multicolumn{2}{|c|}{ Rata-Rata } & \multicolumn{2}{c|}{$\begin{array}{c}\text { Tingkat Keberhasilan } \\
\text { Indikator (Peubah) } \\
\text { PHBS }\end{array}$} \\
\cline { 2 - 6 } & $\begin{array}{c}\text { Gerombol } \\
1\end{array}$ & $\begin{array}{c}\text { Gerombol } \\
2\end{array}$ & $\begin{array}{c}\text { Gerombol } \\
1\end{array}$ & $\begin{array}{c}\text { Gerombol } \\
2\end{array}$ \\
\hline 1 & $\begin{array}{c}\text { Persalinan Kesehatan } \\
\text { (Linakes) }\end{array}$ & 90.01 & 97.7 & Baik & Baik \\
\hline 2 & $\begin{array}{c}\text { Memberi ASI } \\
\text { Eksklusif }\end{array}$ & 38.95 & 78.01 & Buruk & $\begin{array}{c}\text { Cukup } \\
\text { Baik }\end{array}$ \\
\hline 3 & $\begin{array}{c}\text { Menimbang Balita } \\
\text { Setiap Bulan }\end{array}$ & 54.45 & 82.94 & Kurang & Baik \\
\hline 4 & Air Bersih & 63.1 & 95.61 & $\begin{array}{c}\text { Cukup } \\
\text { Baik }\end{array}$ & Baik \\
\hline 5 & CTPS & 44.53 & 89.5 & Buruk & Baik \\
\hline 6 & $\begin{array}{c}\text { Menggunakan Jamban } \\
\text { Sehat }\end{array}$ & 67.14 & 88.32 & $\begin{array}{c}\text { Cukup } \\
\text { Baik }\end{array}$ & Baik \\
\hline 7 & $\begin{array}{c}\text { Memberantas Jentik } \\
\text { di Rumah }\end{array}$ & 52.49 & 84.08 & Kurang & Baik \\
\hline 8 & $\begin{array}{c}\text { Makan Sayur dan } \\
\text { Buah-buahan }\end{array}$ & 48.1 & 78.51 & Buruk & $\begin{array}{c}\text { Cukup } \\
\text { Baik }\end{array}$ \\
\hline 9 & $\begin{array}{c}\text { Melakukan Aktifitas } \\
\text { Fisik }\end{array}$ & 52.24 & 89.46 & Kurang & Baik \\
\hline 10 & $\begin{array}{c}\text { Tidak Merokok di } \\
\text { Rumah }\end{array}$ & 30.11 & 67.16 & Buruk & $\begin{array}{c}\text { Cukup } \\
\text { Baik }\end{array}$ \\
\hline
\end{tabular}

(1) Gerombol 1, terdiri dari puskesmas Seberang Padang, Pengambiran, Bungus, Naggalo, Alai, Anak Air, Pauh, dan Lubuk Kilangan.

(2) Gerombol 2, terdiri dari puskesmas Pemancungan, Ikur Koto, Air Dingin, Kuranji, Ambacang, Rawang Barat, Lubuk Begalung, Ulak Karang, Padang Pasir, Andalas, Belimbing, Air Tawar, Lubuk Buaya, dan Lapai.

Puskesmas-puskesmas yang termasuk pada Gerombol 1 masih banyak yang belum menerapkan perilaku hidup bersih dan sehat. Hal tersebut mungkin dapat disebabkan rendahnya pengetahuan atau kesadaran masyarakat terhadap perilaku hidup bersih dan sehat didalam kehidupan sehari-hari, sehingga membuat program masing-masing puskesmas pada Gerombol 1 terhadap indikator PHBS belum cukup baik terlaksana.

Puskesmas-puskesmas yang termasuk pada Gerombol 2 jumlah masyarakat yang menerapkan perilaku hidup bersih dan sehat sudah cukup banyak. Pengetahuan dan informasi pada masyarakat untuk hidup bersih dan sehat sudah sangat baik, sehingga membuat program masing-masing puskesmas pada Gerombol 2 terhadap indikator PHBS sudah sangat baik terlaksana. Namun, budaya merokok di dalam rumah maupun didalam kehidupan sehari-hari masih cukup tinggi, ini dikarenakan kesadaran masyarakat yang kurang terhadap bahaya rokok di rumah.

\subsection{Saran}

(1) Di Gerombol 1 masih sangat perlu perhatian dan informasi dalam upaya pentingnya memiliki perilaku hidup bersih dan sehat di dalam kehidupan seharihari.

(2) Pada Indikator tidak merokok di rumah masih perlu perhatian yang lebih banyak oleh pemerintah. Karena pada indikator ini menghasilkan nilai yang 
cukup rendah. Perlunya peran pemerintah dalam memperhatikan indikator tidak merokok di dalam rumah dengan cara memberikan suatu program kepada masyarakat untuk meningkatkan perilaku tidak merokok di rumah.

\section{Daftar Pustaka}

[1] Anwar, U.P. 2011. Penggerombolan Kabupaten/kota di Sumatera Barat Berdasarkan Pemerataan Sarana dan Prasarana Pendidikan. Skripsi-S1, tidak diterbitkan.

[2] Departemen Kesehatan R.I. 2011. Perilaku Hidup Bersih dan Sehat di Rumah Tangga, Jakarta.

[3] Dinas Kesehatan Kota Padang. 2013. Profil Kesehatan, Padang.

[4] Dinas Kesehatan Kota Padang. 2014. Promkes dan Pemberdayaan Masyarakat, Padang.

[5] Hardle, W. dan L. Simar. 2007.Applied Multivariate Statistical Analysis, Second Edition. Springer Berlin Heidelberg, New York.

[6] Johnson, R. A. dan D. W. Wichern. 1998. Applied Multivariate Statistical Analysis, Prestice-Hall, Inc., New Jersey.

[7] Susetyo, B. 2003. Analisis Peubah Ganda, Jurusan Statistika FMIPA IPB, Bogor.

[8] Oktavia, S. dan M. N. Mara , 2001, Pengelompokan kinerja Dosen Jurusan Matematika FMIPA Untan Berdasarkan Penilaian Mahasiswa Menggunakan Metode Ward, Jurnal Matematika dan Statistika 2 : 93 - 100 